D.E. Peterson, K.L. Finger, S. Iepure, S. Mariani, A. Montanari, and T. Namiotko - Ostracod assemblages in the Frasassi Caves and adjacent sulfidic spring and Sentino River in the northeastern Apennines of Italy. Journal of Cave and Karst Studies, v. 75, no. 1, p. 1127. DOI: $10.4311 / 2011$ PA0230

\title{
OSTRACOD ASSEMBLAGES IN THE FRASASSI CAVES AND ADJACENT SULFIDIC SPRING AND SENTINO RIVER IN THE NORTHEASTERN APENNINES OF ITALY
}

\author{
Dawn E. Peterson ${ }^{1}$, Kenneth L. Finger ${ }^{*}$, Sanda Iepure², Sandro Mariani ${ }^{3}$, \\ Alessandro Montanari ${ }^{4}$, and Tadeusz Namiotko ${ }^{5}$
}

\begin{abstract}
Rich, diverse assemblages comprising a total (live + dead) of twenty-one ostracod species belonging to fifteen genera were recovered from phreatic waters of the hypogenic Frasassi Cave system and the adjacent Frasassi sulfidic spring and Sentino River in the Marche region of the northeastern Apennines of Italy. Specimens were recovered from ten sites, eight of which were in the phreatic waters of the cave system and sampled at different times of the year over a period of five years. Approximately 6900 specimens were recovered, the vast majority of which were disarticulated valves; live ostracods were also collected. The most abundant species in the sulfidic spring and Sentino River were Prionocypris zenkeri, Herpetocypris chevreuxi, and Cypridopsis vidua, while the phreatic waters of the cave system were dominated by two putatively new stygobitic species of Mixtacandona and Pseudolimnocythere and a species that was also abundant in the sulfidic spring, Fabaeformiscandona ex gr. F. fabaeformis. Pseudocandona ex gr. P. eremita, likely another new stygobitic species, is recorded for the first time in Italy. The relatively high diversity of the ostracod assemblages at Frasassi could be attributed to the heterogeneity of groundwater and associated habitats or to niche partitioning promoted by the creation of a chemoautotrophic ecosystem based on sulfur-oxidizing bacteria. Other possible factors are the geologic age and hydrologic conditions of the cave and karst aquifer system that possibly originated in the earlymiddle Pleistocene when topographic uplift and incision enabled deep sulfidic waters to reach the local carbonate aquifer. Flooding or active migration would have introduced the invertebrates that now inhabit the Frasassi Cave system.
\end{abstract}

\section{INTRODUCTION}

Due to their toxic level of $\mathrm{H}_{2} \mathrm{~S}$ and critically low concentration of dissolved oxygen, the environment of a sulfur-based chemoautotrophic groundwater ecosystem is considered harsher than other subsurface settings (Engel, 2007). Despite the stressful sulfidic environment, it is remarkable that their crustacea-dominated fauna appear to be as diverse as those in non-sulfidic karst ecosystems, especially when considering endemics (Culver and Sket, 2000; Iliffe, 2004). Since the discoveries of thermal vent communities in the 1970s (Jannasch, 1985; Deming and Barross, 1993) and the Movile Cave in 1986 (Sarbu, 1990; Sarbu et al., 1996), several subsurface ecosystems associated with sulfidic waters, particularly in caves, were documented worldwide as hotspots for subterranean biodiversity (Iliffe, 2004). However, the ostracod fauna are almost unknown for most of the discovered sulfidic cave and karst aquifers.

The best-known hotspot of ostracod biodiversity is the anchialine Walshingham Cave System in Bermuda, with nineteen ostracod species out of a total thirty animal species registered (Iliffe, 2004). Other hotspots of subterranean crustacean biodiversity are known in continental sulfidic karst systems, but their associated ostracod faunas are less diverse. The Movile Cave in Romania hosts one endemic ostracod species of Pseudocandona (awaiting formal description) out of a total of eighteen aquatic species (Sarbu et al., 1996; Sarbu et al., 2000). The large Edwards Aquifer in Texas, from which springs provide the base flow of the Guadalupe River system, also hosts only one known ostracod species, Sphaeromicola moria Hart, among its fifty-five known aquatic taxa (Longley, 1981, 1986). Ostracods have yet to be studied in other sulfidic ecosystems that support diverse communities of stygobitic crustaceans, such as the thermohaline sulfidic spring complex of El Hamma in Tunisia (Por, 1963), the Dead Sea rift valley and the Ayalon Cave in Israel (Por, 1963, 2007, 2011), the springs of Grotta di Fiume Coperto in Italy (Latella et al., 1999), Lower Kane Cave in Wyoming, USA (Porter et al., 2002; Engel, 2007), and Cueva de Villa Luz in Mexico (Engel, 2007).

\footnotetext{
* Corresponding author: kfinger@berkeley.edu

${ }^{1}$ University of California Museum of Paleontology, 1101 Valley Life Sciences Building, Berkeley, CA 94720-4780, USA

${ }^{2}$ Speleological Institute "Emil Racovitza", Department of Biospeleology, Clinicilor 5, 400006, Cluj Napoca, Romania

${ }^{3}$ Gruppo Speleologico CAI Fabriano, Via Alfieri 9, 60044 Fabriano, Italy

${ }^{4}$ Osservatorio Geologico di Coldigioco, Cda. Coldigioco 4, 62021 Apiro, Italy

${ }^{5}$ University of Gdańsk, Department of Genetics, Laboratory of Limnozoology, Kładki 24, 80-822 Gdańsk, Poland
}

Journal of Cave and Karst Studies, April 2013•11 

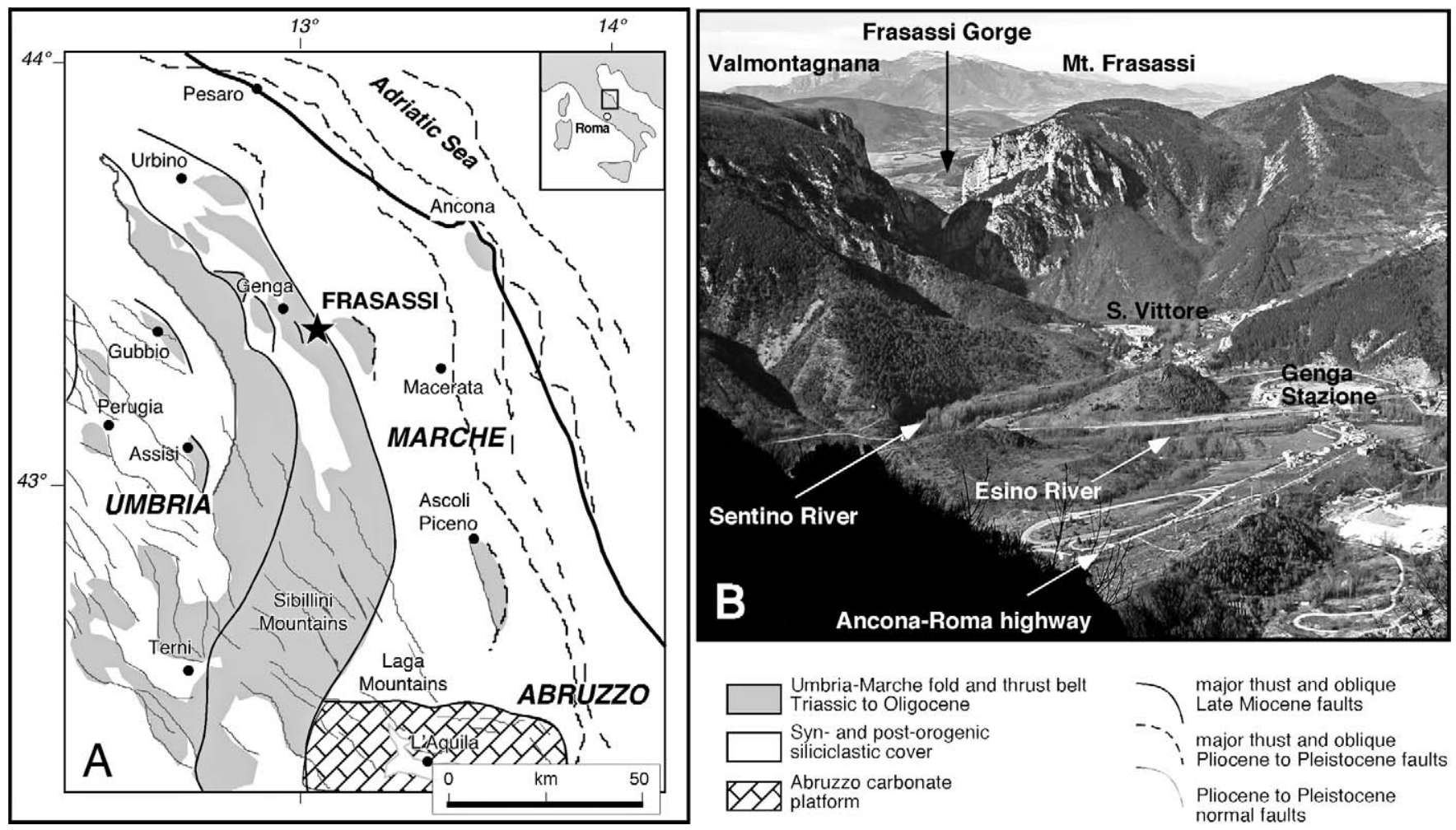

Figure 1. (A) Simplified geostructural map of the Umbria-Marche region and location of the Frasassi area. (B) Panoramic view of the Frasassi area looking west.

During a joint expedition in 2001, speleologists of the Gruppo Speleologico of the Club Alpino Italiano from Fabriano and the Gruppo Speleologico Marchigiano in Ancona discovered and explored a new large extension in the deepest reaches of the Grotta del Fiume in the Marche region of central Italy, which, along with another dozen or so other caves, is part of the sulfidic chemioautotrophic ecosystem of the hypogenic karst of Frasassi (Fig. 1; entrance coordinates: $43^{\circ} 24^{\prime} 03^{\prime \prime} \mathrm{N} ; 12^{\circ} 57^{\prime} 48^{\prime \prime} \mathrm{E}$ ). In this newly discovered part of the cave, named New Mexico, the speleologists found the bones and skin of hundreds of subfossil eels (Anguilla anguilla L.) lying on the subvertical banks of large phreatic lakes up to about $5 \mathrm{~m}$ above the water table (Fig. 2).

Taphonomy and carbon-isotope analysis of the eel remains indicate that the animals periodically entered the cave from the Sentino River that flows outside the cave through the deep Frasassi Gorge. The eels survived in this hypogean environment feeding on sulfur bacteria (Mariani et al., 2007), which still flourish in the sulfidic bottomwater layer of these phreatic lakes (Macalady et al., 2008a, b). These chemosynthetic, autotrophic sulfur bacteria are the food source for a number of stygobionts endemic to the cave, including protozoans (Buonanno et al., 2009), annelids (Erséus, 2009), rotifers (Claudia Ricci, personal communication, January 2010), gastropods (Bodon et al., 2009), copepods (Diana Galassi, personal communication,
October 2009), and amphipods (Bauermeister, 2009; Dattagupta, 2009; Karaman et al., 2010; also see review by Montanari, 2010). After dying, the decomposing eels floated on the surface of these phreatic pools, and after heavy rains the slow northward backflow of vadose bicarbonate water washed them up onto the rocky banks (Mariani et al., 2007). Through accurate radiocarbon dating of the eel remains, Mariani et al. (2007) obtained corrected ${ }^{14} \mathrm{C}$ ages that increased with height above present mean water table from $2200 \mathrm{BP}$ at $63 \mathrm{~cm}$, to $2600 \mathrm{BP}$ at $215 \mathrm{~cm}$, to $7200 \mathrm{BP}$ at $395 \mathrm{~cm}$. Using a radiocarbon age of 8400 BP from a calcite rind contouring the lakes at $465 \mathrm{~cm}$, Mariani et al. (2007) estimated that the water table dropped at a mean rate of about $0.55 \mathrm{~mm} \mathrm{y}^{-1}$ during the Holocene because of the incision of the Sentino River and the tectonic uplifting of the Frasassi area.

While preparing samples for radiocarbon dating, Mariani et al. (2007) recovered numerous well-preserved shells of microgastropods and ostracods that had been intimately mixed with the eel debris (Fig. 2C). Stygobitic hydrobiid microgastropods $(\sim 1 \mathrm{~mm})$ belonging to the genus Islamia were first reported in the sulfidic sections of the Frasassi caves by Sarbu et al. (2000) as a component of its hypogean fauna that included fourteen other species of mostly terrestrial invertebrates, five of which were new taxa and seven of which were endemic to these caves. They reported only two inhabitants of the aqueous environment 

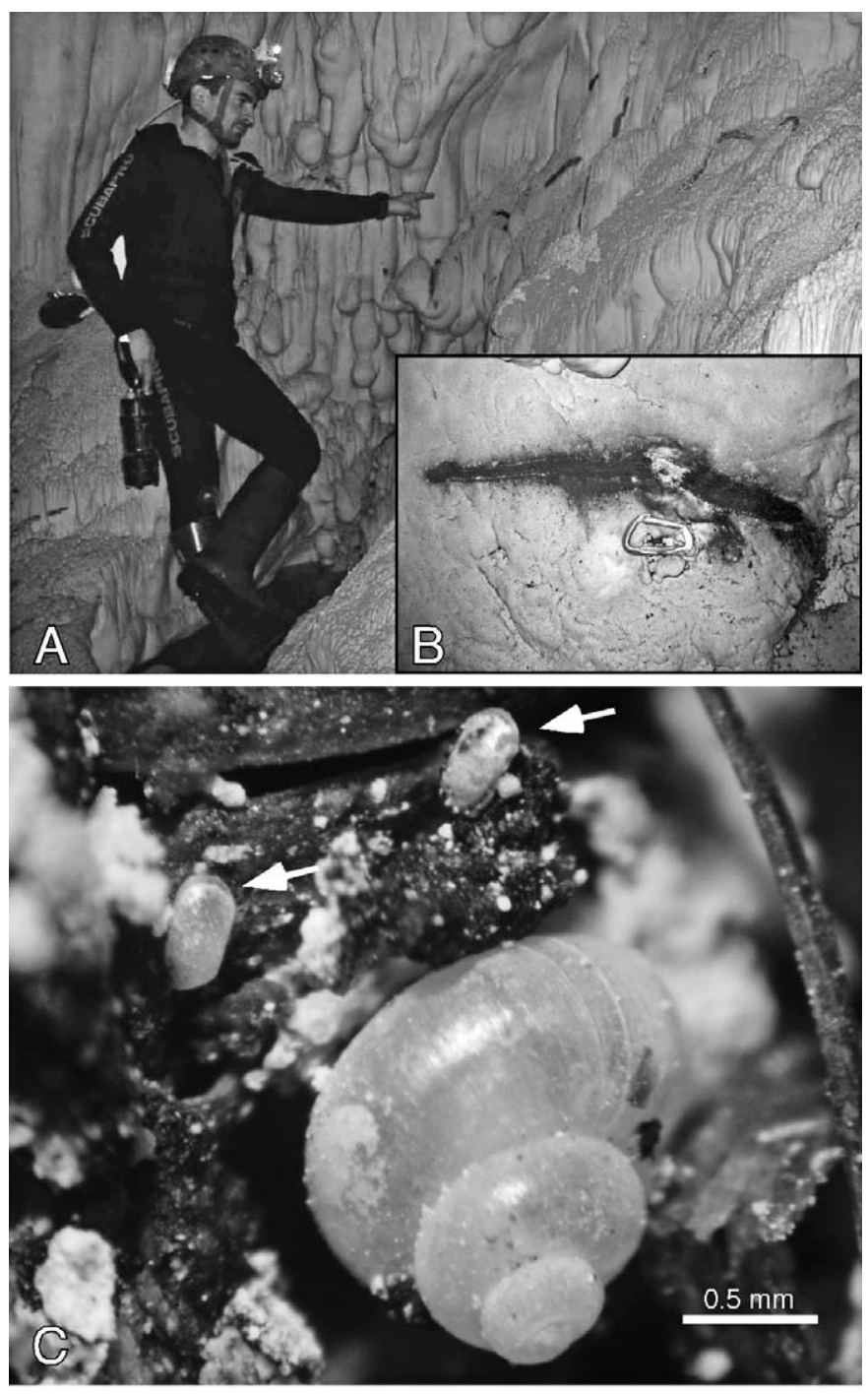

Figure 2. (A) Subfossil eels attached to a vertical concretioned bank of Lago delle Anguille. (B) Detail of a sampled eel found at about $2 \mathrm{~m}$ above the water table. (C) Photomicrograph of subfossil eel debris (skin and bones; sample LDA/09/09-200 cm) with a shell of the gastropod Islamia sp. 2 and two carapaces of the ostracod Pseudolimnocythere sp. (arrows).

in the cave, the amphipod Niphargus ictus Karaman and the microgastropod Islamia pusilla (Piersanti). In a subsequent study on these microgastropods, Bodon et al. (2009) identified them as Islamia sp. 2, an undescribed species known only from this cave system and provisionally identified from a few sulfidic springs in Umbria and Latium.

The discovery of abundant ostracod shells among the remains of subfossil (Holocene but not recent) eels prompted our study of them in several phreatic lakes and pools throughout the cave system, as well as in and around a sulfidic spring outside the cave and on the banks of the Sentino River. In this paper, we present a reconnaissance of these ostracod assemblages that focuses on their ecological characteristics and distribution. We highlight two new stygobitic species, here reported in open nomenclature as Mixtacandona sp., which is apparently endemic to the Frasassi cave system, and an elusive yet intriguing Pseudolimnocythere sp., which is represented by more than one thousand subfossil carapaces and valves recovered from various sites in the cave. We report also on a third presumably new stygobitic or stygophilic species, Pseudocandona ex gr. $P$. eremite that was recovered rarely and only from the Frasassi sulfidic spring, and eighteen other ostracod species collected from localities along the riverbanks and the sulfidic spring. Detailed taxonomic descriptions of the three new species will be addressed in the future.

\section{Geologic Setting}

The Frasassi Cave system is a $25 \mathrm{~km}$ karstic maze located in the Mt. Frasassi-Mt. Valmontagna blind-thrust anticline, which is part of the Umbria-Marche Apennines thrust-and-fold belt of central Italy (Fig. 1). The core of the anticline is made of a $800 \mathrm{~m}$ thick succession of massive carbonate platform limestone layers of the Calcare Massiccio Formation (earliest Jurassic), overlain by a succession of Jurassic to Eocene pelagic limestone formations (Fig. 3). The Calcare Massiccio rests on top of the uppermost Triassic Burano Formation, which consists of a $2000 \mathrm{~m}$ thick succession of evaporitic anhydrites, black shales, and bituminous limestones (Martinis and Pieri, 1964). The Burano evaporites are not exposed in the Frasassi area, but are present in deep boreholes, and they are quarried in some localities near Perugia, in Umbria.

The anticline is dissected by the deep Frasassi Gorge, which was incised by the eastward-flowing Sentino River, a tributary of the Esino River. The Sentino flows at piezometric level in the Frasassi Gorge, which corresponds to the height of the water table in the cave system, at about $205 \mathrm{~m}$ above mean sea level toward the eastern end of the gorge. The incision of the gorge was the result of a combined process of antecedence and superposition beginning during the Pleistocene (Mazzanti and Trevisan, 1978; Alvarez, 1999). The core of the anticline was karstified during this time, with the formation of the giant Frasassi Cave system, which comprises seven main subhorizontal levels connected by narrow, steep to nearly vertical shafts (Fig. 4). This is the result of alternating erosion and deposition controlled by successive Quaternary glacial-interglacial cycles during a steady, regional tectonic uplift (Cattuto, 1976; Bocchini and Coltorti, 1990; Galdenzi and Menichetti, 1995; Mayer et al., 2003; Cyr and Granger, 2008; Wegman and Pazzaglia, 2008). Some large rooms, such as the $250 \mathrm{~m}$ high Abisso Ancona (estimated at $10^{6} \mathrm{~m}^{3}$ ), were created by the collapse of the thin rock layers separating the hypogean levels. The lowest level is flooded by the water table and represents the piezometric level of the cave system.

Journal of Cave and Karst Studies, April 2013•13 


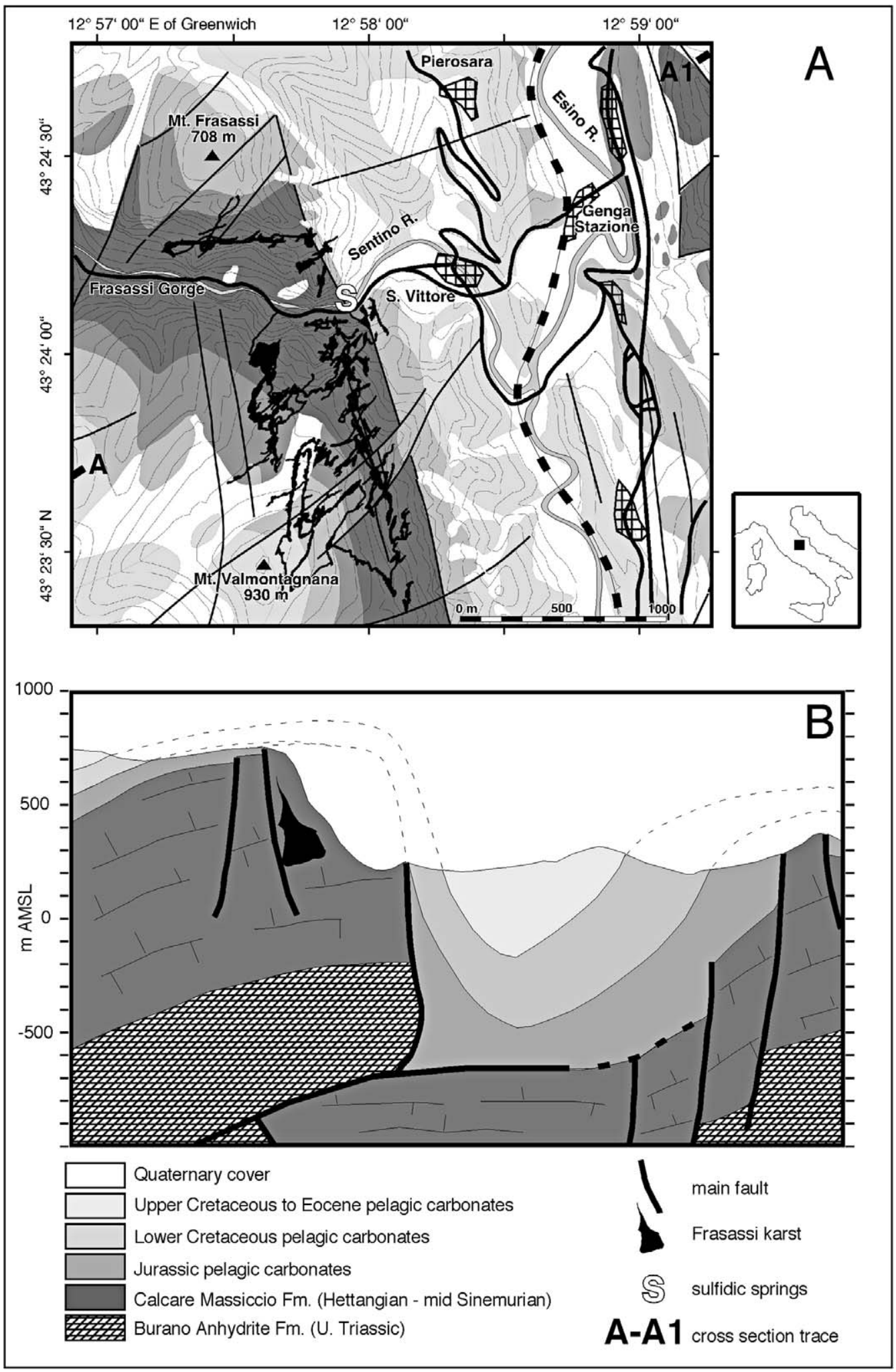

Figure 3. (A) Simplified geologic map. (B) Cross-section of the Frasassi area. (Redrawn from Mariani et al., 2007.) 


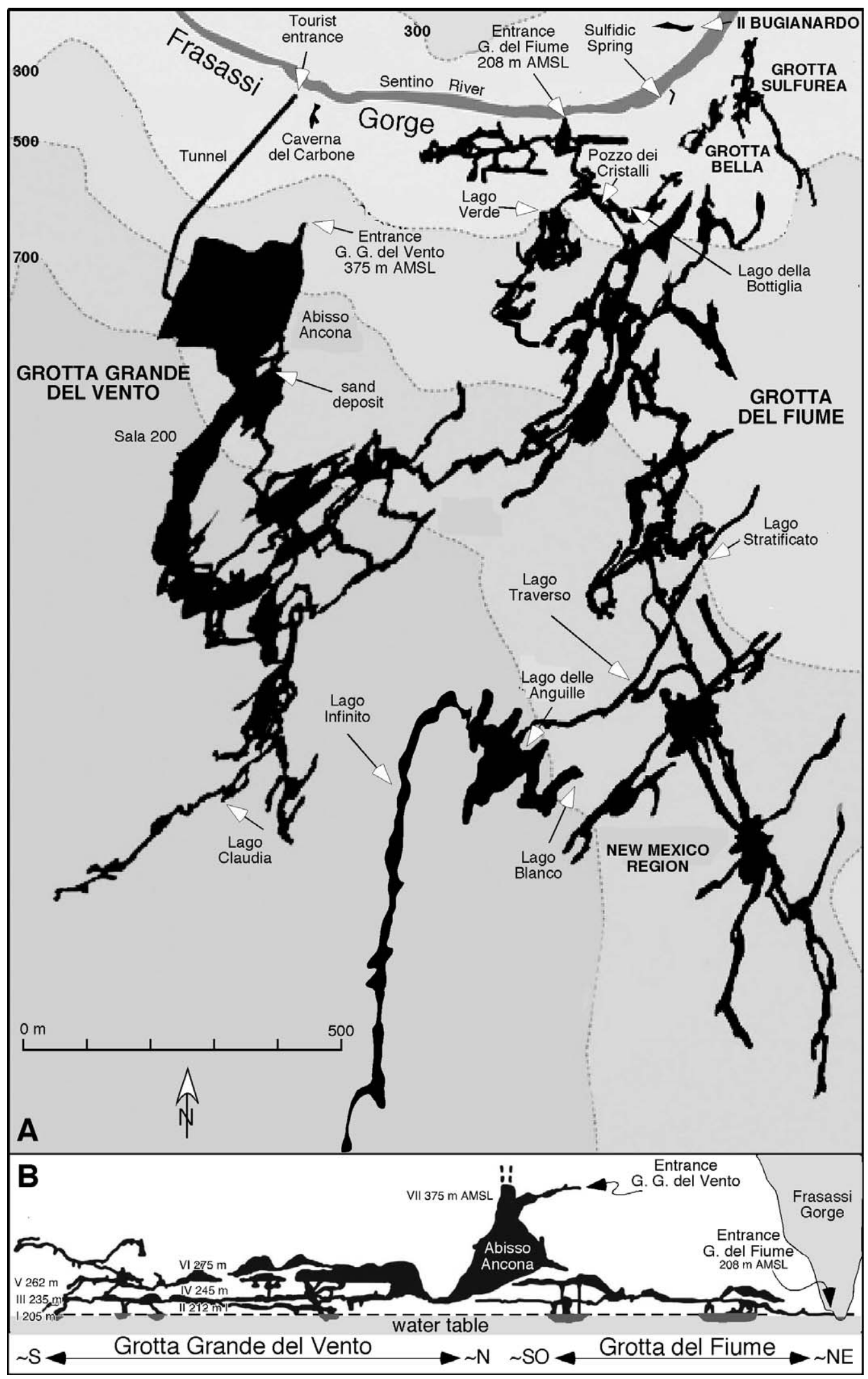

Figure 4. (A) Simplified map of the Grotta Grande del Vento-Grotta del Fiume cave system (base map from Mariani et al., 2007) with location of sites cited in the text. (Note: this plane view of the complex cave system does not show the vertical extent of the first four levels of the cave from its base level of $205 \mathrm{~m}$ AMSL to $\sim 245 \mathrm{~m}$ elevation). (B) Idealized cross-section of the caves showing the arrangement of horizontal hypogean levels. 
Deep groundwater contacting the Burano Formation reduces the anhydrite, allowing sulfidic $\mathrm{H}_{2} \mathrm{~S}$-rich water to well up along the fault that bounds the east side of the Frasassi anticlinal massif, eventually emerging along the intersection of this fault with the Sentino River bed (see Fig. 3).

The presence in the Burano Formation of anhydrite $\left(\mathrm{CaSO}_{4}\right)$ as a sulfate source and black shale as an organic carbon source provides the conditions for bacterial sulfate reduction in deep groundwater to form $\mathrm{H}_{2} \mathrm{~S}$. Bacterial action is necessary in this reducing process because $\mathrm{H}_{2} \mathrm{~S}$ would not be produced inorganically at any significant rate at temperatures below $200^{\circ} \mathrm{C}$ (Druschel et al., 2009). The $\mathrm{H}_{2} \mathrm{~S}$-rich water wells up along the fracture network until it interacts with oxygen brought in either as dissolved $\mathrm{O}_{2}$ in meteoric water percolating from above through the Calcare Massiccio limestone or as atmospheric $\mathrm{O}_{2}$ in the open spaces of the cave system. At this point, the $\mathrm{H}_{2} \mathrm{~S}$ interacts with the oxygen, creating conditions for sulfur-oxidizing bacteria to accelerate the rate of the overall reaction and liberate $\mathrm{H}^{+}$to form sulfuric acid $\left(\mathrm{H}_{2} \mathrm{~S}+2 \mathrm{O}_{2} \rightarrow 2 \mathrm{H}^{+}\right)$that corrodes and dissolves the limestone $\left(\mathrm{CaCO}_{3}\right)$ of the Calcare Massiccio, thus forming the hypogenic cave system within the water table. Such a reaction, which would be extremely slow without the action of the sulfur bacteria, precipitates gypsum $\left(\mathrm{CaSO}_{4} \cdot 2 \mathrm{H}_{2} \mathrm{O}\right)$, which, being soluble in water, is carried away out of the cave system with the slow but continuous flow of vadose water. In some parts of the cave, sulfidic water reaches the surface, exhaling $\mathrm{H}_{2} \mathrm{~S}$ directly into the cave atmosphere. This causes corrosion of the limestone vaults, formation of microcrystalline gypsum slush masses (Galdenzi and Maruoka, 2003), and the growth of extremely acidic pendulous biofilms (snottites) attached to the walls of the cave (Macalady et al., 2007, Jones et al., 2012). In summary, the giant Frasassi Cave system is the result of sulfidic hypogenic karstification in which sulfur-oxidizing bacteria play a major role in the massive corrosion of the Calcare Massiccio limestone (Galdenzi et al., 1999, 2008; Macalady et al., 2006, 2008a). Continuous and abundant production of organic matter by the $\mathrm{H}_{2} \mathrm{~S}$-oxidizing bacterial activity is the basis of a complex stygobitic ecosystem.

\section{Materials And Methods}

During 2005-2010, eighty samples were collected for ostracods from ten Frasassi localities). These included fifteen small samples of subfossil eel remains (bones and skin), ranging from 0.1 to $5.0 \mathrm{~g}$ each, collected in 20052007 at eight different heights above water table (50, 70, $150,200,215,300,370$, and $395 \mathrm{~cm}$ ) on the banks of Lago delle Anguille in the New Mexico region of the Grotta del Fiume (see Fig. 4A for location). Ostracod carapaces and valves were separated from organic eel remains with a moist fine brush and mounted on micropaleontological slides for examination.

A total of twenty-two sediment samples were systematically collected at different times of the year from spring 2005 to winter 2010 from eight phreatic lakes in the Grotta del Fiume-Grotta Grande del Vento complex. In order of progressively greater distance from the natural entrance of the Grotta del Fiume, these are Lago Verde, L. della Bottiglia, L. Stratificato, L. Traverso, L. Blanco, L. delle Anguille, L. Infinito, and L. Claudia (Fig. 4A). Arm length limited substrate sampling to water depths ranging up to $60 \mathrm{~cm}$. Except for Lago della Bottiglia, where sampling was done in 2009 and 2010 using a plankton net, all sediment samples were collected in $3 \mathrm{~L}$ sealable plastic bags containing abundant cave water using an ordinary $7 \mathrm{~cm}$ diameter metal tea strainer as a scooper. A few hours after their collection, samples were wetscreened at the Geological Observatory of Coldigioco to remove sediment smaller than $63 \mu \mathrm{m}$ and greater than $2 \mathrm{~mm}$; the residues were preserved in $50 \mathrm{~mL}$ Falcon tubes with $70 \%$ ethanol for transport to the University of California Museum of Paleontology, where the residues were again washed through a $63 \mu \mathrm{m}$ sieve. Each dried residue was split into 63, 125 and $250 \mu \mathrm{m}$ fractions for stereomicroscopic examination; all ostracod specimens were picked and sorted on micropaleontological slides. Images of selected specimens were obtained using the Hitachi TM-1000 Tabletop Scanning Electron Microscope at the Robert M. Ogg Electron Microscope Laboratory, University of California, Berkeley.

It is important to point out that, despite our intention to perform sampling in the most systematic and consistent way possible, difficult environmental conditions that vary between lakes and sampling sites hindered our attempts to obtain a sample collection that would be appropriate for an accurate quantitative assessment of the ostracod assemblages in the cave. Only experienced and technically proficient cavers can reach many of the sites, particularly the inner lakes of the Grotta del Fiume (Fig. 5). Hence, sampling was limited to sites where a lake's bank is relatively easy to reach and has a gentle or flat slope that enabled us to easily collect fine sediment from shallow depths.

At Lago della Bottiglia (Fig. 5A) in the Grotta del Fiume and in all the larger, up to $8 \mathrm{~m}$ deep lakes in the New Mexico region of the cave, the sulfidic water layer is usually at a depth of approximately $4 \mathrm{~m}$ (Mariani et al., 2007). Therefore samples were collected well above the chemocline, in oxygenated bicarbonate water. On the other hand, at Lago Verde and Lago Claudia (Figs. 6C, D), sulfidic water often reaches the water table, and the sediment along the banks is usually black in color, reduced, and rich in hydrogen sulfide (Figs. 6B, D). In most cases, cave-lake sediments were usually made of micro- or cryptocrystalline calcite or clay, sometimes containing iron-sulfide grains, and, at the Lago Infinito sampling site, microcrystals of gypsum. Where the bank of the lake is a talus slope, as at Lago Verde and Lago Claudia, the sediment consists of fine grains to large angular fragments of limestone. In contrast, the sparse sediment attached to the steep, rocky bank of Lago della Bottiglia at the bottom of Pozzo dei Cristalli (Fig. 4A) consists of calcite microcrystals and fecal pellets of the hygrobiid gastropod Islamia sp. 2. 
One sample was collected at Lago Claudia in summer 2008 experimenting with a suction pump with a $63 \mu \mathrm{m}$ polyester monofilament cloth as catching filter and kept in water to be observed in a $12 \mathrm{~cm}$ diameter Petri dish at the Coldigioco lab. From this sample, live ostracod specimens were separated and preserved in $70 \%$ ethanol for later identification. After discovering live specimens at Lago Claudia, in 2009 we adopted the use of a $20 \mathrm{~cm}$ diameter polyester plankton net with a $44 \mu \mathrm{m}$ mesh and a $50 \mathrm{~mL}$ Falcon tube as terminal catcher for further sampling in this relatively accessible site, and we also used it at Lago della Bottiglia (see Fig. 4A for locations).

Twenty-four sediment samples from the Frasassi sulfidic spring were collected at different times of the year from winter 2006 through summer 2009. The sampling site is a small, ephemeral pond on the left side of the sulfidic stream, which flows for a few meters out of the calcareous massif through a small cave before merging into the right bank of the Sentino River (Fig. 7A). The pond is protected from the direct flow of the river by boulders. The reduced, sulfidic sediment of the pond includes lime, calcareous sand, and pebbles derived from the various formations of the Umbria-Marche sedimentary succession, mostly pelagic limestones and chert from the Jurassic to Oligocene part of the succession, and siliceous sand, silt, and clay from the Miocene flysch succession (Marnoso-Arenacea Formation). All samples from this site contained abundant leaf and woody litter. Collecting was performed during low river flow. During prolonged periods of heavy rains, usually in the early winter and early spring, the Sentino River floods, rising to $3 \mathrm{~m}$ above normal level. During these events, the ephemeral sulfidic spring and pond are completely submerged by the rushing, muddy river water (Fig. 7B). It usually takes a week or more of dry weather for the Sentino to return to its low, normal flow regime and for the sulfidic environment of our sampling site to regenerate.

Seven riverbed sediment samples were taken in 2006 and 2009 along the right bank of the Sentino 15 and $30 \mathrm{~m}$ upstream and 5 and $10 \mathrm{~m}$ downstream from the sulfidic Spring. One sample was also collected on the left bank about $15 \mathrm{~m}$ directly across the river from the sulfidic spring site. These fluvial deposits were used for comparison with samples from the cavern and sulfidic spring.

Due to the difficulty of sampling the bottom waters of the hypogean lakes, there are no measurements of their oxygen concentrations. Among profiles of redox potential measurements versus depth obtained in 2009 for a few lakes, those for Lago Infinito and Lago Profondo showed they were well stratified, with a sharp chemocline above water with oxygen below detection limits of $\sim 6 \mu \mathrm{g} \mathrm{L}^{-1}$ or $0.2 \mu \mathrm{mol} \mathrm{L}{ }^{-1}$. The well-mixed sulfidic stream was not anoxic, but had very low oxygen levels. (J. Macalady, pers. comm.)

\section{RESUlts}

In total, sixty-six of the eighty Frasassi samples yielded 6850 ostracod specimens representing twenty-one species-group taxa (Table 1; Figure 8) belonging to fifteen genera and five families (Candonidae, Ilyocyprididae, Cyprididae, Limnocytheridae, and Loxoconchidae). The seventy-seven assemblage slides prepared in this study reside in the University of California Museum of Paleontology microfossil collection as UCMP 46331-46407. Table 1 records the numbers of valves and live specimens of each taxon at the ten Frasassi localities. However, it must be pointed out that the number of valves per species in Table 1 is not a standardized measure of the absolute abundance relative to a unit of sediment surface, mass, or volume, nor is it of the abundance of specimens in one site relative to another. Each site was sampled multiple times, some more times than others, and the amount of sediment recovered varied. The total amount of sediment analyzed also varies from site to site. Nevertheless, the specimen counts reveal the relative abundance of each species at each location.

Out of the twenty-one species identified, three stygobites are of particular interest. Numerous valves and live individuals identified as Mixtacandona sp. (Fig. 8G) most likely represent a new species that closely resembles Mixtacandona talianae Gliozzi and Mazzini and M. italica Karanovic and Pesce. Mixtacandona talianae was described from valves recovered from Holocene cave deposits in Grotta del Lago in Umbria, central Italy (Gliozzi and Mazzini, 1998a), while M. italica was collected live from groundwater accessed through wells in Puglia, southeastern Italy (Karanovic and Pesce, 2000). Our specimens are similar to these two species in having a trapezoidal left valve, a height:length ratio greater than $55 \%$, and remarkable dorsal protuberances. But Mixtacandona sp. can be distinguished by its straight or only slightly concave valve margin in the anterodorsal and posterodorsal sections, unlike that of $M$. talianae and $M$. italica, where it is distinctly concave, and by its larger size (valve length 0.70 to $0.75 \mathrm{~mm}$ vs. 0.54 to $0.57 \mathrm{~mm}$ for $M$. talianae and 0.57 to $0.62 \mathrm{~mm}$ of $M$. italica). The Frasassi specimens differ also in soft-part features that await detailed study and description.

Triangular valves of other putative new stygobitic candonid species found in sediments of the Frasassi sulfidic spring were assigned to Pseudocandona ex gr. P. eremita (Fig. 8F) based on the diagnosis of Namiotko and Danielopol (2004). This open nomenclature is used because several species belonging to this group presently cannot be unambiguously separated without thorough analysis of valve shape and male genital morphology (see Iepure et al., 2007). Although the taxonomic status of our specimens remains to be determined by further study, the occurrence of Pseudocandona ex gr. P. eremita in the sulfidic spring allows us to extend the known geographical distribution of the $P$. eremita group, as this is the first record of a representative of this stygobitic ostracod group in Italy. It also allows us to revise the ecological valences of this group previously known only from non-sulfidic waters.

As for Pseudolimnocythere sp., the third stygobitic ostracod found at Frasassi (Fig. 8U), it shows closest

Journal of Cave and Karst Studies, April 2013・17 



Figure 5. Phreatic lakes of the Frasassi caves sampled for this study (see Fig. 4). (A) Lago della Bottiglia; arrow points to a whiskey bottle at the bottom of a $30 \mathrm{~cm}$ deep pond on the right side of the pool; the sample site is on the steep rocky bank at the lower left. (B) Lago Stratificato; note the rafts of microcrystalline calcite that form at the water surface during the dry season. (C) Lago Traverso. (D) Lago delle Anguille; inner tube of tire and caver climbing on the right side provide scale. (E) Lago Blanco, so named because of the white lime on the shallow lake bottom. (F) Lago Infinito, which is in the farthest reaches of the Grotta del Fiume and is the largest lake in the cave, at approximately $200 \mathrm{~m}$ long and $8 \mathrm{~m}$ deep. Sampling site LIN is in the northern part of the lake. 



Figure 6. (A) Lago Verde, the phreatic pool closest to the natural entrance of the Grotta del Fiume cave sampled in this study. Samples were taken from the shallow, muddy edge of the pool, beyond which the lake drops several meters. The concentration of $\mathrm{H}_{2} \mathrm{~S}$ in the superficial water layer may change considerably through time due to the seasonally variable water table and the relatively shallow sulfidic water layer. (B) Closeup of the sampling site on the shore of Lago Verde. Note the numerous amphipods Niphargus ictus pasturing in a $5 \mathrm{~cm}$ deep pond on the shore of the lake. The lake bottom consists of black, reduced, sulfidic mud mixed with rocks from the bank's scree. (C) Lago Claudia, the sampled phreatic pool farthest from the natural entrance of the cave. (D) Shallow bottom along margin of Lago Claudia showing the angular limestone clasts derived from the talus slope that distinguish it from Lago Verde.

affinity to $P$. hypogea Klie, originally described from material collected from groundwater in southern Italy (Klie, 1938) and subsequently recorded in caves and wells in Puglia by Pesce and Pagliani (1999) and Karanovic and Pesce (2001). More recently, individuals of this genus were reported in northern Apennine springs (Bottazzi et al., 2008; Stoch et al., 2009), but they were not described. It is unfortunate that none of the Frasassi Pseudolimnocythere sp. specimens retain their soft parts, as the limb and genital morphology in the genus are better characteristics for distinguishing species than valve morphology alone. Future detailed study on the valve morphology and additional material with soft parts will enable us to confirm the taxonomic status of our specimens.

Some other taxa in the studied material are also left in open nomenclature (Table 1, genus and species indeterminate) to indicate that the identification to the species level was provisional, uncertain, or impossible due to the lack of soft parts or an insufficient number of well-preserved adult valves. The senior author tentatively identified some

Journal of Cave and Karst Studies, April 2013•19 

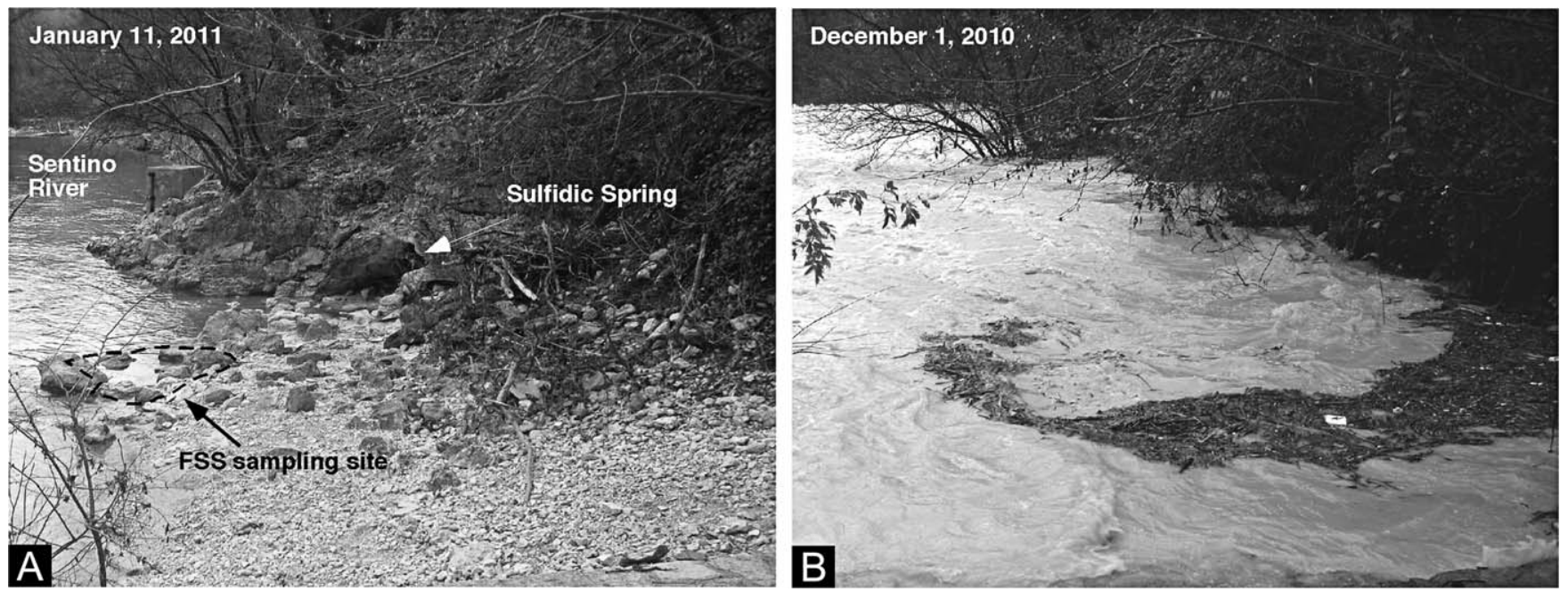

Figure 7. (A) View of the sulfidic spring site taken on January 11, 2011; the sampling site is delimited by a dashed line. (B) The same site during heavy flooding of the Sentino River on December 1, 2010, when both the small pond of the sampling site and the cave where the sulfidic water flows out from the mountain and into the Sentino are completely submerged by muddy river water.

broken valves from the sulfidic spring as belonging to two other species of Mixtacandona and one species of Cryptocandona, suggesting a greater species diversity of groundwater-associated ostracod assemblages in the Frasassi cave system. However, as verification of this material was impossible, these taxa were excluded from further study pending the availability of sufficient material.

Apart from the three presumably new species (Mixtacandona sp., Pseudocandona ex gr. P. eremita, and Pseudolimnocythere sp.), two candonid species identified only to the species group (Candona ex gr. C. neglecta and Fabaeformiscandona ex gr. F. fabaeformis), and an unidentified species of Paralimnocythere, all taxa listed in Table 1 have been previously reported from various habitats elsewhere in Europe (Meisch, 2000). They have been also recorded from various present-day water bodies and late Pliocene to Holocene deposits in the Italian Peninsula, Sardinia, and Sicily (e.g., Ambrosetti et al., 1995; Barberi et al., 1995; Calderini et al., 1998; Gliozzi and Mazzini, 1998b; Gliozzi, 2000; Meisch, 2000; Karanovic and Pesce, 2001; Rossi et al., 2003, 2004; Rossetti et al., 2004, 2005, 2006; Pieri et al., 2006, 2007, 2009; Rossi et al., 2010).

In the epigean site of the sulfidic spring pool (FSS in Table 1), live specimens collected were limited to Candona ex gr. C. neglecta, Fabaeformiscandona ex gr. F. fabaeformis, Ilyocypris monstrifica, Prionocypris zenkeri, Cypridopsis vidua, Potamocypris zschokkei, and Limnocythere inopinata. Prioncypris zenkeri was the most abundant taxon, represented by 1541 valves and six live individuals from the sulfidic spring. Valves of most of these species were also recovered from non-sulfidic sediment samples collected along the banks of the Sentino River, but the live fauna recovered consisted only of eight specimens of Fabaeformiscandona ex gr. F. fabaeformis (FSR in Table 1).
Inside the cave at Lago Verde, the sampled phreatic pool closest to the natural entrance of the Grotta del Fiume ( $\sim 150 \mathrm{~m}$ straight-line distance), we found 281 valves of many of the taxa recovered outside plus one live specimen of Pseudocandona albicans. The most abundant ostracod species at Lago Verde, represented by 82 valves, is Candona ex gr. C. neglecta (LVE in Table 1). Two live juveniles of this taxon were recovered elsewhere, one from the sulfidic spring and another, interestingly enough, at Lago Claudia, the most remote lake in the inner part of the Grotta Grande del Vento, about $1.2 \mathrm{~km}$ straight-line distance from the natural entrance of that cave (Fig. 4A).

Hundreds of specimens of Mixtacandona sp., Pseudolimnocythere sp., and Fabaeformiscandona ex gr. fabaeformis were recovered from the most remote sites of the cave system, as well as a very few valves of Candona neglecta, Candona ex gr. C. neglecta, Pseudocandona albicans, Herpetocypris chevreuxi, and Cypridopsis vidua, rarely found in sites closer to an entrance.

Of the three most abundant species in the hypogean environment of Frasassi, only Mixtacandona sp. was found live and abundant at Lago della Bottiglia and Lago Claudia. Empty valves of this species were present in all the other sampled cave sites, as well as the sulfidic spring outside the cave, but none were recognized in any of the samples from the freshwater sites along the Sentino River banks. Lago Blanco yielded a disproportionate 383 valves of Mixtacandona sp., 325 of which were in sample LBL/0721/04. Valves of this species were also found among subfossil eel remains at Lago delle Anguille, at 395, 300, 150 , and $70 \mathrm{~cm}$ above the present water table. The limy sediment of Lago Blanco also produced a disproportionate number of Fabaeformiscandona ex gr. F. fabaeformis, which occurred as 435 valves, 325 of which were in the same

20 - Journal of Cave and Karst Studies, April 2013 
D.E. Peterson, K.L. Finger, S. Iepure, S. Mariani, A. Montanari, and T. Namiotko

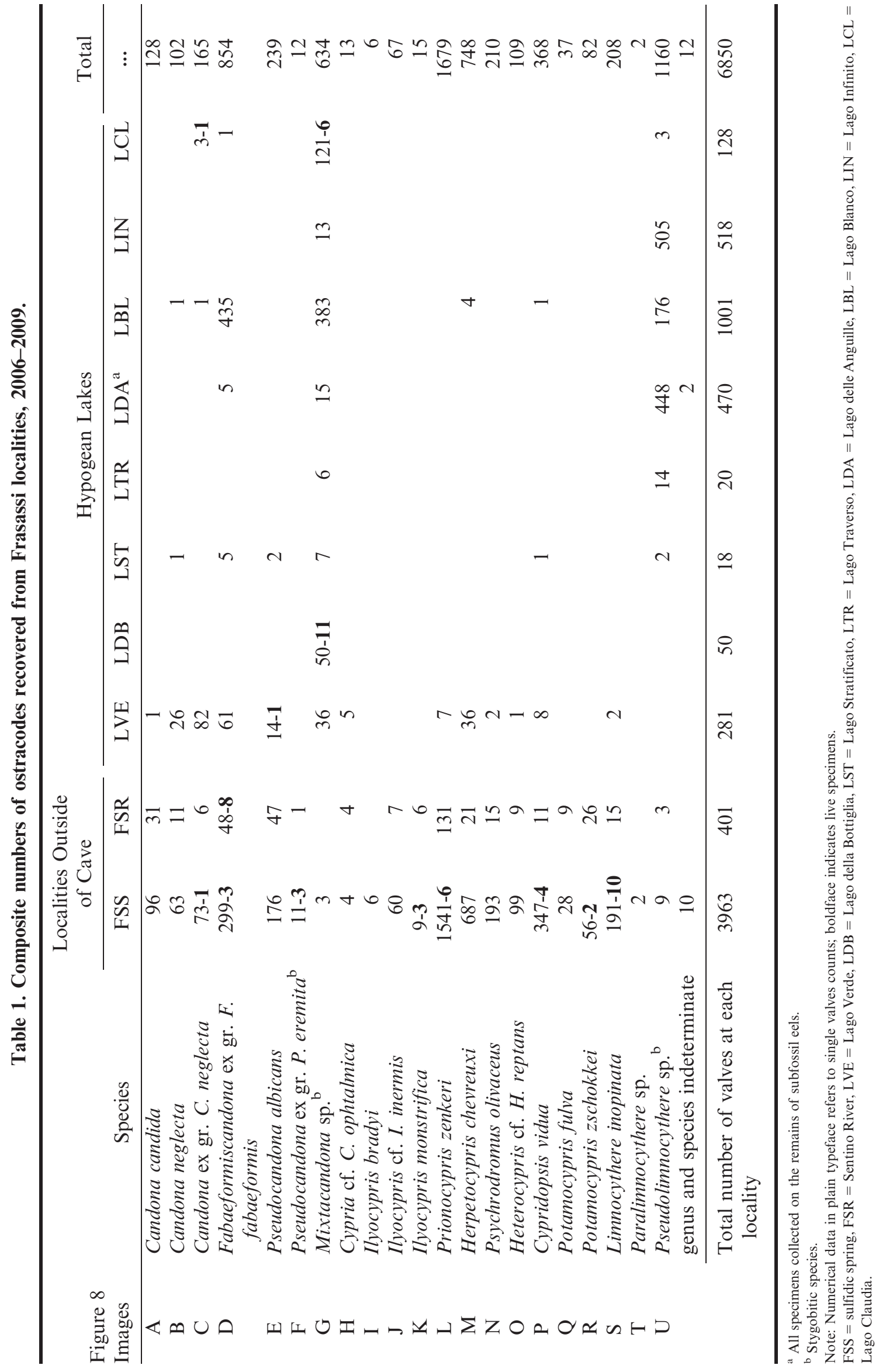

Journal of Cave and Karst Studies, April 2013•21 


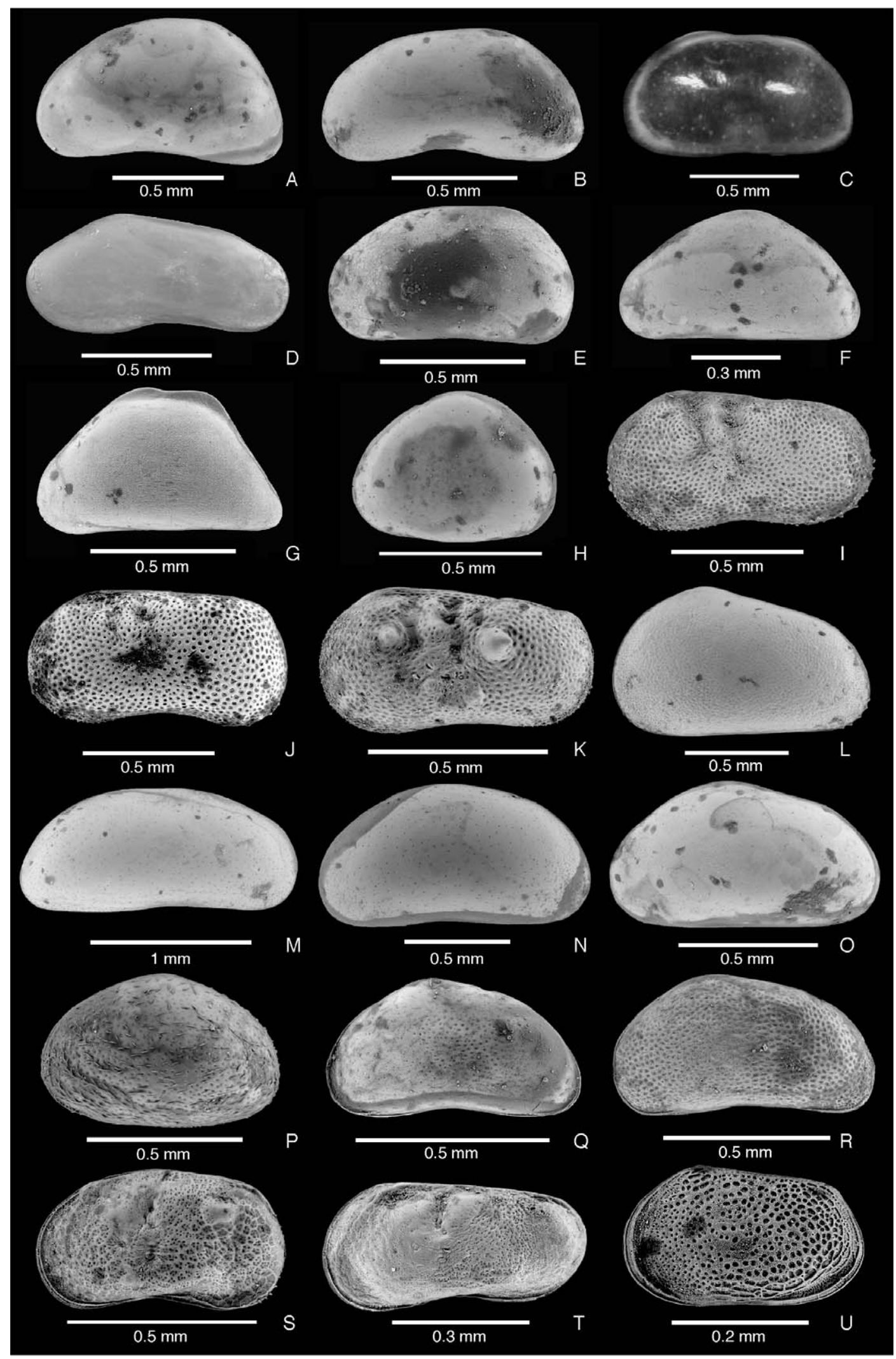

Figure 8. External lateral views of ostracod valves from the Sentino River, sulfidic spring, and cave complex at Frasassi. All are SEM images except $C$, which is a photomicrograph. $L V=$ left valve; $R V=$ right valve. (A) Candona candida (Müller, 1776), LV. (B) Candona neglecta Sars, 1887, LV. (C) Candona ex gr. C. neglecta, LV. (D) Fabaeformiscandona ex gr. F. 
sediment sample that yielded the same number of Mixtacandona sp.

The distribution of Pseudolimnocythere sp. is intriguing, because this species is represented in our collection by 1160 carapaces and valves but no live specimens. Only nine disarticulated valves were found at the sulfidic spring site, where 3954 valves belonging to other species were recovered. Just three valves were found in nonsulfidic riverbank sediments, where 398 valves of other species were counted. Few separate valves were recovered from samples collected at the hypogean sites of Lago Stratificato, Lago Traverso, and Lago Claudia. Yet 176 valves (articulated carapaces counted as two valves) of Pseudolimnocythere sp. were counted in samples from Lago Blanco, 505 valves at Lago Infinito, and an abnormally large total number of 448 valves were recovered from eight small samples of subfossil eel remains collected at 50, 70, 150, 200, 215, 300, 375 , and $395 \mathrm{~cm}$ above the present water table at Lago delle Anguille. Considering that a total of only five valves of Fabaeformiscandona ex gr. F. fabaeformis and fifteen valves of Mixtacandona sp. were recovered from the subfossil eel samples, it appears that Pseudolimnocythere sp., though probably extinct by now, had been the dominant ostracod species of the Frasassi cave system in the recent past.

In the studied material, Pseudolimnocythere sp. was represented predominantly by separate adult valves, which may indicate some evidence of taphonomic postmortem disturbance or biological activity (Boomer et al., 2003). However, in samples large enough to provide a significant number of specimens (ca. >150), separate valves were accompanied by closed carapaces with the mean valve:carapace ratio $\pm \mathrm{SD}=21.8 \pm 9.7$ (based on four abundant samples from Lago Blanco, Lago Infinito, and Lago delle Anguille). At Lago delle Anguille, Pseudolimnocythere sp. was found in seventeen samples with varied abundances, six of which had only separate valves. The other eleven samples had valve:carapace ratios that ranged from 1:1 to $75: 1$ with the mean value $\pm \mathrm{SD}=12.2 \pm 21.7$. This predominance of valves, however, may be biased, because carapaces of this very small species (adult length < $0.35 \mathrm{~mm}$ ), especially juveniles, are more prone than those of larger species to disarticulation resulting from chemical and biological decomposition of soft parts, as well as physical separation during sample collection and processing. Nevertheless, we believe that our record represents an autochthonous assemblage preserved in situ (i.e., thanatocoenosis sensu Boomer et al., 2003), and as such, it is a good indicator of an accumulation representing an in situ life environment.

\section{DisCUSSION}

\section{HABITATS}

From this reconnaissance study, our first impression is that the main selective factor for the Frasassi ostracod assemblages is the hydrogen sulfide contained in the waters of the sulfidic spring and the hypogean lakes that requires special adaption to both the toxicity of $\mathrm{H}_{2} \mathrm{~S}$ and the hypoxia in these environments. Sulfur bacteria, which thrive in these sulfidic waters, provide a limitless and constant food source for those ostracods that can adapt to the conditions and diet. In contrast, in non-sulfidic, epigean waters, the food source normally consists of algae and other vegetal or animal matter. In terms of environmental or ecologic characteristics, the main difference between the sulfidic spring and the cave sites is that the latter are aphotic. In addition, the environmental conditions in the phreatic pools of the cave are much more stable than those of the sulfidic spring pond, which gets obliterated several times a year by floodwaters of the Sentino River.

It is remarkable that Mixtacandona sp. and Candona ex gr. $C$. neglecta seem to be the only ostracods living permanently, at least since the early Holocene, in the phreatic waters of the cave system. Our Mixtacandona sp. displays morphological traits typical for a stygobite dweller with a long evolutionary history of isolation underground, being diaphanous, depigmented, transparent, small-sized, and anophtalmic.

\section{Hypogean Colonization}

Some questions remain about how and when ostracods colonized the groundwater habitats of the Frasassi Cave system. They either entered gradually by actively passing through interstices and fractures of the limestone bedrock below the water table or they were introduced passively en mass via episodic flooding of the cave when the Sentino River flowed at the same elevation as large natural entrances. However, the ostracod richness and endemicity in the Frasassi area is probably due to both species-habitat specialization and

fabaeformis (Fischer, 1851), RV. (E) Pseudocandona albicans (Brady, 1864), LV. (F) Pseudocandona ex gr. P. eremita (Vejdowský, 1882), LV. (G) Mixtacandona sp., LV. (H) Cypria ophtalmica (Jurine, 1820), LV. (I) Ilyocypris bradyi Sars, 1890, LV. (J) Ilyocypris cf. I. inermis Kaufmann, 1900, LV. (K) Ilyocypris monstrifica (Norman, 1862), LV. (L) Prionocypris zenkeri (Chyzer \& Toth, 1858), LV. (M) Herpetocypris chevreuxi (Sars, 1896), RV. (N) Psychrodromus olivaceus (Brady \& Norman, 1889), LV. (O) Heterocypris reptans (Kaufmann, 1900), LV. (P) Cypridopsis vidua (Müller, 1776), LV. (Q) Potamocypris fulva (Brady, 1868), LV. (R) Potamocypris zschokkei (Kaufmann, 1900), LV. (S) Limnocythere inopinata (Baird, 1843), LV. (T) Paralimnocythere sp., LV. (U) Pseudolimnocythere sp., RV. 
the general factors that act in any subterranean ecosystem, like the age of the system, karst isolation, and the underground colonization history at the regional level.

At present, a number of cave systems' entrances are located on the Mt. Valmontagnana (southern) side of the Frasassi Gorge at elevations between 350 and $500 \mathrm{~m}$ above msl (e.g., Buco Cattivo, Grotta del Paradiso, Grotta dell'Infinito, Buco del Diavolo, Grotta dell'Inferno; see Cattuto, 1976). Although karstic morphology and rare residual gypsum deposits in these caves indicate that sulfidic activity was present in the phreatic environment when the Sentino River was flowing at these elevations, the lack of geochronological data prevent an accurate assessment of the age of formation of these upper and older karstic levels. Moreover, no evidence of fossil stygobitic animals has yet been found in the sediments of these caves. Cyr and Granger (2008) obtained an Al/Be cosmogenic age of $760 \pm 250 \mathrm{ka}$ from a fluvial deposit preserved in the Grotta della Beata Vergine, on the Mt. Frasassi (northern) side of the gorge at an elevation of $325 \mathrm{~m}$. This suggests that a sulfidic hypogean environment capable of supporting a complex chemoautotrophic ecosystem was present in this area in the late-early Pleistocene and that the Sentino River could have transported epigean organisms in the cave system via episodic floods.

The only natural cave entrance known on the slopes of the Frasassi Gorge at an elevation lower than $325 \mathrm{~m}$, besides the Grotta del Fiume, is that of the Caverna del Carbone, a small cave located near the tourist entrance of the Grotta Grande del Vento, at $236 \mathrm{~m}$ (i.e., $\sim 31 \mathrm{~m}$ above present river level). The floor of the Caverna del Carbone is alluvium, mostly clay, some sand, and pebbles. An impenetrable clay deposit presently obstructs the inner tunnel of the cave that leads southward toward the Grotta Grande del Vento. Coincidently, a well-sorted, fine-sand fluvial deposit preliminarily dated with the optical-stimulated-luminescence method on quartz at $111 \pm 17 \mathrm{ka}$ (Markus Fiebic, pers. comm. on work in progress) is located in the northernmost end of Sala 200 (see Fig. 4A for location) in the Grotta Grande del Vento, at an elevation of $234 \mathrm{~m}$, corresponding to the third level of the cave system. In both these fluvial deposits, we found well-preserved ostracod valves representing essentially the same species that we collected from the Sentino River site. Besides Candona candida, C. neglecta, C. ex gr. C. neglecta, Ilyocypris bradyi, I. gibba, Potamocypris sp., and juvenile cypridid valves that most probably represent species found today in the Sentino River, such as Heterocypris cf. H. reptans or Psychrodromus olivaceus), as well as rare valves of Mixtacandona sp., these paleoassemblages include two other species, Cyclocypris cf. C. ovum (Jurine) and Potamocypris fallax Fox, that were not recorded in the Sentino River, sulfidic spring, or Frasassi Cave system. These observations allow no doubt that the Sentino River was flooding the cave during the Riss-Würm interglacial period, importing organisms from outside the cave into the cave's phreatic environment.
At present, the Sentino River flows approximately $3 \mathrm{~m}$ below the natural entrance of the Grotta del Fiume. The study by Mariani et al. (2007) on the subfossil eels demonstrates that there have been, as far back as 7200 years ago, open passages below the water table through which these fish were able to enter the hypogean environment and swim to the deepest and farthest reaches of the cave system. It is reasonable to think that other outsiders were able to enter the cave along with the eels, and some of them were able to adapt to its environment. We found valves of three ostracod species mixed with the subfossil remains of these eels: Mixtacandona sp., Fabaeformiscandona ex gr. $F$. fabaeformis, and unusually abundant Pseudolimnocythere sp. Of these, only Mixtacandona sp. presently lives exclusively in the same cave environments. In recent years, eels have been observed swimming in a small pool in the Grotta Solfurea about $80 \mathrm{~m}$ from the Sentino River (Fig. 4A; pers. comm. by Piero Mirabella and Sandro Galdenzi and sighting by Alessandro Montanari in 1973). If anything, this indicates that there must be at least one direct connection between the Sentino River and the cave system. Alternatively, it may be that exceptionally heavy flooding of the Sentino River, like the one in the winter of 2010, would have swollen the river level high enough to reach the Grotta del Fiume entrance, allowing the river water to rush into the cave transporting sediment and live aquatic animals, including fish and ostracods. Further research on the cave sediments will hopefully provide greater insight on the history of ostracod colonization of this extraordinary cave system.

\section{Ecology and Trophic Adaptation}

The recovery of only one live specimen, a juvenile, of Candona ex gr. C. neglecta at Lago Claudia and only one live Pseudocandona albicans at Lago Verde prevents us from making any assessment on the ecology and trophic adaptations of these ostracods living today in the phreatic environment of the Frasassi cave system. On the other hand, something can be said in regard to Mixtacandona sp., which thrives in the phreatic waters of Lago della Bottiglia and Lago Claudia. The accessibility and morphology of the Lago della Bottiglia (Fig. 5A) makes possible a rough estimate of how many specimens live in a square meter of the lake's bank at any time. This small yet deep lake has a stratified water column, with a layer of well-oxygenated bicarbonate water at the surface and a layer of sulfidic water down to a depth of 3 to $4 \mathrm{~m}$. During an expedition to this site in September 2009, live specimens of Mixtacandona sp. were captured by gently brushing the $20 \mathrm{~cm}$ diameter rigid rim of a conical plankton net against the steep, rocky banks of the lake with slow, repeated movements from about $50 \mathrm{~cm}$ depth upward to the surface. During thirty such strokes, about $2 \mathrm{~m}^{3}$ of water passed through the net over about $0.5 \mathrm{~m}^{2}$ of the lake's rocky bank, with a total catch of about $25 \mathrm{~cm}^{3}$ of fine sediment containing twenty-five shells of the hygrobiid gastropod

24-Journal of Cave and Karst Studies, April 2013 
Islamia sp. 2, several Niphargus ictus, a few nematodes, a few dozen copepods, about fifty disarticulated ostracod valves, and eleven live individuals of Mixtacandona sp. No other ostracod species were recognized in the catch. Sampling was repeated at different times in the following year at this site using the same procedure (thirty strokes over the same bank surface), and a catch of ten to fifteen live specimens was consistently obtained, leading to the conclusion that, at this site, twenty to thirty specimens were living on a square meter of rocky bank. As mentioned above, the sparse sediment attached to the rocky bank is mostly made of Islamia sp. 2 fecal pellets. Direct observation of this gastropod in mesocosms over a period of three years (see review by Montanari, 2010), revealed that it feeds on bacteria by pasturing on the glass wall of the tank along the boundary between the deep sulfidic water layer and the overlying bicarbonate water layer, where the highest concentration of benthic microorganism such as bacteria, protozoans, nematodes, platyhelminthes, and rotifers were found. But for most of the time, the gastropods crawl on the glass walls of the mesocosms well above the chemocline, in oxygenated, bicarbonate waters, and never descend into the euxinic bottom-water layer. These observations led us to hypothesize that ostracods and other stygobitic meiofauna such as copepods find gastropod fecal pellets to be an important trophic resource in Lago della Bottiglia.

The trophic situation at Lago Claudia is different than that deduced at Lago della Bottiglia. At Lago Claudia, the sulfidic bottom-water layer often reaches the lake's surface, with $\mathrm{H}_{2} \mathrm{~S}$ escaping into the cave's atmosphere. The northern bank of this deep pool is the base of a gentle limestone talus slope (Figs. 6C, D) that is often reached by the chemocline, particularly during the dry season in summer and early autumn. In these times, the bottom of the shallow bank is sulfidic and reduced, and it is capped by a layer of bicarbonate water just a few centimeters thick. Live specimens of Mixtacandona sp. were recovered from this site in July 2008 (sample LCL/08.07/04) and observed in a Petri dish, where they were distinctly seen grazing on threads and feathers of sulfur-oxidizing bacteria on rocks and clay in the substrate sample.

An additional distinct trophic adaptation is suggested by the presence of Mixtacandona sp., Fabaeformiscandona ex gr. F. fabaeformis, and abundant Pseudolimnocythere sp. on the remains of subfossil eels at Lago delle Anguille (Table 1), along with numerous shells of the gastropod Islamia sp. 2. Our samples of these remains were small scrapings from which it was impossible to determine if the microgastropods and ostracods had been ingested by the eels or if they had been feeding on the remains. However, a complete specimen collected later clearly shows them scattered on the outer surface of the skin, suggesting that they were necrophagous. We believe the presence of these organisms on the eel carcasses is somewhat analogous to the extreme, ephemeral deep-sea ecosystem that develops on a fallen whale (Dominici et al., 2009, and references therein). These carcasses, such as the Pliocene whale studied by Dominici et al. (2009) in Tuscany, serve as a long-lasting food source for a welldiversified invertebrate fauna dominated by gastropods, bivalves, decapods, and worms in an otherwise extreme, oligotrophic, and mainly chemosymbiotic environment.

All considered, we conclude that Mixtacandona sp., as well as other endemic ostracod species found in the phreatic waters of the Frasassi cave system, are benthonic stygobitic grazers dwelling in oxygenated waters not far from a sulfidic chemocline, which constantly provides them with a limitless food supply of sulfur bacteria. The ostracods are opportunistic feeders that adapt to local trophic provisions, such as abundant fecal pellets of gastropods and occasional fallen eels.

\section{Conclusions}

The 6850 specimens of twenty-one species of ostracods recovered over five years of sampling at the Frasassi cave system and the adjacent sulfidic spring and Sentino River constitute the largest and most diversified collection to date of these microcrustaceans from a continental sulfidic cave and karst aquifer. The dominant species differ between the assemblages inside and outside the cave. The cave fauna includes three apparently new stygobitic species. Import by river floods and gradual migration, trophic opportunism, and environmental heterogeneity have contributed to and maintained the species diversity at a relatively higher level than is typical for freshwater environments. Future studies of this sort should enable us to better understand the ecology and evolution of hypogeal ostracods, and, in turn, the ostracods may find utility in deciphering the evolution and environmental health of individual cave systems.

\section{ACKNOWLedgements}

In December 2009, while working on the most recent collection of Frasassi ostracods, Dawn Peterson was diagnosed with brain cancer, and she was no longer able to continue with her research; she passed away on June 29, 2010. With this report, we did our best to finalize the work she began in 2006. This was made possible by Dawn's scrupulous annotations of every sample collected over five years, and, as her research progressed, the constant flow of information that she provided to us during the course of her study, including tabulated raw data, SEMs, literature searches, and comments on direct observations. Dan Danielopol kindly assisted Dawn in identifying the new species and by providing useful information and advice.

The authors thank the Federazione Speleologica Marchigiana for grants received from the Regional Assessor to the Protected Areas, Kyoto Protocol, and Urban Requalification for the research project on the aquatic fauna of the Frasassi Caves and sulfidic spring and for covering

Journal of Cave and Karst Studies, April 2013 • 25 
logistical and travel costs for Dawn Peterson during the sampling campaigns in July 2006, July 2008, and October 2009. Financial support is also acknowledged for speleological equipment and laboratory materials for preliminary analyses and sample preparation provided by the Observatorio Geologico di Coldigioco (OGC). At UC Berkeley, Walter Alvarez kindly funded Dawn's final month of SEM time. Additionally, we are indebted to Simone Cerioni of the Speleologic Group of Genga, Maurizio Mainiero of the Marchean Speleologic Group of Ancona, Samuele Carnevali of the Gruppo Speleologico of Fabriano, and Maxwell Montanari of the OGC for technical support in the sampling campaigns from the summer of 2006 through the winter of 2010. We would like to thank Greg Drushel, Markus Fiebig, Marco Bodon, Simone Cianfanelli, Jenn Macalady, Emilio Insom, Antonietta La Terza, Sharmistha Dattagupta, Jan Bouermeister, Jean-Francois Flot, Mahesh Desai, Betty and Richard Borowsky, Daniel Jones, Sandro Galdenzi, Christer Erséus, Claudia Ricci, and Diana Galassi for providing information about the stygobitic ecosystem of the Frasassi Caves they are currently studying. We are also grateful to David J. Horne and an anonymous reviewer for their useful comments and suggestions on the manuscript.

\section{REFERENCES}

Alvarez, W., 1999, Drainage on evolving fold-thrust belts: a study of transverse canyons in the Apennines: Basin Research, v. 11, p. 267284. doi: 10.1046/j.1365-2117.1999.00100.x.

Ambrosetti, P., Basilici, G., Capasso Barbato, L., Carboni, M.G., Di Stefano, G., Esu, D., Gliozzi, E., Petronio, C., Sardella, R., and Squazzini, E., 1995, Il Pleistocene inferiore nel ramo Sud-Occidentale del Bacino Tiberino (Umbria): aspetti litostratigrafici e biostratigrafici: Il Quaternario, v. 8, p. 19-36.

Barberi, R., Cavinato, G.P., Gliozzi, E., and Mazzini, I., 1995, Late Pliocene-Early Pleistocene paleoenvironmental evolution of the Rieti basin (central Apennines): Il Quaternario, v. 8, p. 515534.

Bauermeister, J., 2009, Ecology and diversity of an amphipod-bacterial ectosymbiosis from the Frasassi cave complex in central Italy: Abstracts with Program, The Frasassi Stygobionts and Their Sulfidic Environment, Genga, September 10-13, 2009, 7 p.

Bocchini, A., and Coltorti, M., 1990, Il complesso carsico Grotta del Fiume-Grotta Grande del Vento e l'evoluzione geomorfologica della Gola di Frasassi: Memorie dell'Istituto Italiano di Speleologia, ser. 2, v. 4 , p. $155-180$.

Bodon, M., Cianfanelli, S., and Montanari, A., 2009, Mollusks of the Frasassi karstic complex and adjacent sulfidic spring: Abstracts with Program, The Frasassi Stygobionts and Their Sulfidic Environment, Genga, September 10-13, 2009, p. 9-11.

Boomer, I., Horne, D.J., and Slipper, I.J., 2003, The use of ostracods in palaeoenvironmental studies, or what can you do with an ostracod shell?, in Park, L.E., and Smith, A.J., eds., Bridging the Gap: Trends in the Ostracode Biological and Geological Sciences, Ithaca, New York, Paleontological Society Papers no. 9, p. 153-179.

Bottazzi, E., Bruno, M.C., Mazzini, M., Pieri, V., and Rossetti, G., 2008, First report on Copepoda and Ostracoda (Crustacea) from northern Apenninic springs (n. Italy): a faunal and biogeographical account: Journal of Limnology, v. 67, p. 56-63. doi:10.4081/jlimnol.2008.56.

Buonanno, F., Chandramohan, B., Di Pretoro, B., La Terza, A., Ortenzi, C., and Kumar, S., 2009, The protozoan ciliates of the Frasassi caves: a potential source of bioactive molecules for biotechnological applications: Abstracts with Program, The Frasassi Stygobionts and Their Sulfidic Environment, Genga, September 10-13, 2009, $19 \mathrm{p}$.

Calderini, G., Calderoni, G., Cavinato, G.P., Gliozzi, E., and Paccara, P., 1998, The upper Quaternary sedimentary sequence at the Rieti basin (central Italy): a record of sedimentary response to environmental changes: Palaeogeography, Palaeoclimatology, Palaeoecology, v. 140, p. 97-111. doi:10.1016/S0031-0182(98)00024-8.

Cattuto, C., 1976, Correlazione tra piani carsici ipogei e terrazzi fluviali nella valle del Fiume Esino (Marche): Bollettino della Società Geologica Italiana, v. 95, p. 313-326.

Culver, D.C., and Sket, B., 2000, Hotspots of subterranean biodiversity in caves and wells: Journal of Cave and Karst Studies, v. 62, p. 1117.

Cyr, A.J., and Granger, D.E., 2008, Dynamic equilibrium among erosion, river incision, and coastal uplift in the northern and central Apennines, Italy: Geology, v. 36, p. 103-106. doi:10.1130/G24003A.1.

Dattagupta, S., 2009, The Niphargus symbiosis from the Frasassi Cave ecosystem: a case of multiple partners?: Abstracts with Program, The Frasassi Stygobionts and Their Sulfidic Environment, Genga, September 10-13, 2009, 21 p.

Deming, J.W., and Baross, J.A., 1993, Deep-sea smokers: windows to a subsurface biosphere?: Geochimica et Cosmochimica Acta, v. 57, p. 3219-3230. doi:10.1016/0016-7037(93)90535-5.

Dominici, S., Cioppi, E., Danise, S., Betocchi, U., Gallai, G., Tangocci, F., Valleri, G., and Monechi, S., 2009, Mediterranean fossil whale falls and the adaptation of mollusks to extreme habitats: Geology, v. 37, p. 815-818. doi:10.1130/G30073A.1.

Druschel, G.K., Eastman, D., and Macalady, J., 2009, Biological controls on detailed sulfur cycling and the formation of the Frasassi caves: Abstracts with Program, The Frasassi Stygobionts and Their Sulfidic Environment, Genga, September 10-13, 2009, p. 23-24.

Engel, A., 2007, Observations on the biodiversity of sulfidic karst habitats: Journal of Cave and Karst Studies, v. 69, p. 187-206.

Erséus, C., 2009, A possibly opportunistic clitellate annelid belonging to the genus Potamothrix (family Naididae) in the microbial ecosystems of the Frasassi caves (Italy): Abstracts with Program, The Frasass Stygobionts and Their Sulfidic Environment, Genga, September 10 13, 2009, p. 27-28.

Galdenzi, S., and Maruoka, T., 2003, Gypsum deposits in the Frasassi caves, central Italy: Journal of Cave and Karst Studies, v. 65, p. 111-125.

Galdenzi, S., and Menichetti, M., 1995, Occurrence of hypogenic caves in a karst region: examples from central Italy: Environmental Geology, v. 26, p. 39-47. doi:10.1007/BF00776030.

Galdenzi, S., Menichetti, M., Sarbu, S.M., and Rossi, A., 1999, Frasassi caves: a biogenic hypogean karst system?, in Audora, P., ed., Proceedings of the European Conference Karst 99, Université de Provence, Études de Géographie Physique, no. 28, p. 101-106.

Galdenzi, S., Cocchioni, M., Morichetti, L., Amici, V., and Scuri, S., 2008 Sulfidic ground-water chemistry in the Frasassi caves, Italy: Journal of Cave and Karst Studies, v. 70, p. 94-107.

Gliozzi, E., 2000, Tardiglacial-Holocene freshwater ostracod assemblages from Ripasottile wells (Rieti basin, Latium, central Italy): Giornale di Geologia, v. 3, p. 159-172.

Gliozzi, E., and Mazzini, I., 1998a, Mixtacandona talianae n. sp. (Crustacea, Ostracoda) from the Holocene of Grotta del Lago (Ubria, central Italy): Micropaleontology, v. 44, p. 441-446.

Gliozzi, E., and Mazzini, I., 1998b, Palaeoenvironmental analysis of the 250.000-year Quaternary sediment core of Valle di Castiglione (Latium, Italy) using ostracods, in Crasquin Soleau, S., Braccini, E., and Lethiers, F., eds., What about Ostracoda!, Actes du $3^{\mathrm{e}}$ Congrès Européen des Ostracodologistes, 1966, Pau, France, Bulletin du Centres des Recherches ELF Exploration et Production Memoir, v. 20 , p. $69-82$.

Iepure, S., Namiotko, T., and Danielpol, D.L., 2007, Evolutionary and taxonomic aspects within the species group Pseudocandona eremita (Vejdovský) (Ostracoda, Candonidae): Hydrobiologia, v. 585, p. 159-180. doi:10.1007/s10750-007-0636-3.

Iliffe, T.M., 2004, Walsingham Caves, Bermuda: biospeleology, in Gunn, J., ed., Encyclopedia of Caves and Karst Science, New York, Fitzroy Dearborn, p. 767-769.

Jannasch, H.W., 1985, The chemosynthetic support of life and the microbial diversity at deep-sea hydrothermal vents: Proceedings of the Royal Society of London, Ser. B, Biological Sciences, v. 225, p. 277-297. doi:10.1098/rspb.1985.0062.

26• Journal of Cave and Karst Studies, April 2013 
Jones, D.S., Albrecht, H.L., Dawson, K.S., Shaperdoth, I., Freeman, K.H., Pi, Yundan, Pearson, A., and Macalady, J.L., 2012, Community genomic analysis of an extremely acidophilic sulfur-oxidizing biofilm: The ISME Journal, v. 6, p. 158-170. doi:10.1038/ismej.2011.75.

Karaman, G.S., Borowsky, B., and Dattagupta, S., 2010, Two new species of the genus Niphargus Schiödte, 1849 (Amphipoda, fam. Niphargidae) from the Frasassi cave system in central Italy: Zootaxa, no. 2439, p. $35-52$.

Karanovic, I., and Pesce, G.L., 2000, Trapezicandona italica n. sp. from the underground waters of southern Italy (Crustacea, Ostracoda): Fragmenta Entomologica, Roma, v. 32, p. 213-224

Karanovic, I., and Pesce, G.L., 2001, Ostracodes (Crustacea, Ostracoda) from underground waters of Puglia (southern Italy), with a redescription of Pseudolimnocythere hypogea Klie, 1938: Thalassia Salentina, v. 25, p. 11-39. doi:10.1285/i15910725v25p11.

Klie, W., 1938, Ostracoden aus unterirdischen Gewässern in Süditalien: Zoologischer Anzeiger, v. 123, p. 148-155.

Latella, L., Di Russo, C., De Pasquale, L., Dell'Anna, L., and Rampini, M., 1999, Ecological study in a new sulfurous cave from central Italy, in Holcer, D., and Šašic, M., eds., Abstracts of the 14th International Symposium of Biospeleology, Makarska, Croatia 19th-26th September 1999, Croatian Biospeleological Society, $54 \mathrm{p}$

Longley, G., 1981, The Edwards Aquifer: Earth's most diverse groundwater ecosystem? International Journal of Speleology, v. 11, p. 123-128.

Longley, G., 1986, The biota of the Edwards Aquifer and the implications for paleozoogeography: in Abbot, P.L., and WoodruffC.M. Jr., eds., The Balcones Escarpment: Geology, Hydrology, Ecology and Social Development in Central Texas, San Antonio, Texas, Geological Society of America, p. 51-54.

Macalady, J.L., Lyon, E.H., Koffman, B., Albertson, L.K., Meyer, K., Galdenzi, S., and Mariani, S., 2006, Dominant microbial populations in limestone-corroding stream biofilms, Frasassi Cave system, Italy: Applied and Environmental Microbiology, v. 72, p. 5596-5609. doi:10. 1128/AEM.00715-06.

Macalady, J.L., Jones, D.S., and Lyon, E.H., 2007, Extremely acidic, pendulous cave wall biofilms from the Frasassi Cave system, Italy. Environmental Microbiology, v. 9, p. 1402-1414. doi:10.1111/j.14622920.2007.01256.x.

Macalady, J.L., Dattagupta, S., Schaperdoth, I., Jones, D.S., Druschel, G.K., and Eastman, D., 2008a, Niche differentiation among sulfuroxidizing bacterial populations in cave waters: The ISME Journal, v. 2, p. 590-601. doi:10.1038/ismej.2008.25.

Macalady, J.L., Jones, D.S., Schaperdoth, I., Bloom, D., and McCauley, R., 2008b, Meter-long microbial ropes from euxinic cave lakes: American Geophysical Union Fall Meeting 2008, abstract B53C0514 .

Mariani, S., Mainiero, M., Barchi, M., van der Borg, K., van der, Vonhof, H., and Montanari, A., 2007, Use of speleologic data to evaluate Holocene uplifting and tilting: an example from the Frasassi anticline (northeastern Apennines, Italy): Earth and Planetary Science Letters, v. 257, p. 313-328. doi:10.1016/j.epsl.2007.02.045.

Martinis, B., and Pieri, M., 1964, Alcune notizie sulla formazione evaporitica del Triassico superiore nell'Italia centrale e meridionale: Memorie della Società Geologica Italiana, v. 4, p. 649-678.

Mayer, L., Menichetti, M., Nesci, O., and Savelli, D., 2003, Morphotectonic approach to the drainage analysis in the north Marche region, central Italy: Quaternary International, v. 101-102, p. 157-167. doi:10. 1016/S1040-6182(02)00098-8.

Mazzanti, R., and Trevisan, L., 1978, Evoluzione della rete idrografica nell'Appennino centro-settentrionale: Geografia Fisica e Dinamica Quaternaria, v. 1, p. 55-62.

Meisch, C., 2000, Freshwater Ostracoda of western and central Europe, Heidelberg, Spektrum Akademischer Verlag, Süßwasserfauna von Mitteleuropa, v. 8/3, 522 p.

Montanari, A., 2010, ed., Stigobionti: vita acquatica nelle grotte di Frasassi, Jesi, Italy, Federazione Speleologica Marchigiana, $120 \mathrm{p}$.

Namiotko, T., and Danielopol, D.L., 2004, Review of the eremita speciesgroup of the genus Pseudocandona Kaufmann (Ostracoda, Crustacea), with the description of a new species: Revista Española de Micropaleontologia, v. 36, p. 117-134.

Pesce, G.L., and Pagliani, T., 1999, Gli ambientali anchialini della Puglia e la loro fauna, in Belmonti, G., Ciccarese, G., and Ruggiero, L., eds., Il
Carsismo nell-Area Mediterranea, Thalassia Salentina, Supplement to no. 23 , p. $89-102$.

Pieri, V., Martens, K., Naselli-Flores, L., Marrone, F., and Rossetti, G., 2006, Distribution of Recent ostracods in inland waters of Sicily (southern Italy). Journal of Limnology, v. 65, p. 1-8. doi:10.4081/ jlimnol.2006.1.

Pieri, V., Caserini, C., Gomarasca, S., Martens, K., and Rossetti, G., 2007, Water quality and diversity of the Recent ostracod fauna in lowland springs from Lombardy (northern Italy): Hydrobiologia, v. 585 , p. 79-87. doi:10.1007/s10750-007-0630-9.

Pieri, V., Martens, K., Stoch, F., and Rossetti, G., 2009, Distribution and ecology of non-marine ostracods (Crustacea, Ostracoda) from Friuli Venezia Giulia (NE Italy): Journal of Limnology, v. 68, p. 1-15. doi:10.4081/jlimnol.2009.1.

Por, F.D., 1963, The relict aquatic fauna of the Jordan Rift Valley: new contributions and review: Israel Journal of Zoology, v. 12, p. 4758.

Por, F.D., 2007, Ophel: a groundwater biome based on chemoautotrophic resources: The global significance of the Ayalon Cave finds, Israel: Hydrobiologia, v. 592, p. 1-10. doi:10.1007/s10750-007-0795-2.

Por, F.D., 2011, Groundwater life: some new biospeological views resultly from the Ophel paradigm. Travaux Institul de Speologie Emile Racovitza, v. 50, p. 61-76.

Porter, M.L., Russell, S., Engel, A.S., and Stern, L., 2002, Population studies of the endemic snail Physa spelunca (Gastropoda: Physidae) from Lower Kane Cave, Wyoming (abstract): Journal of Cave and Karst Studies, v. 64, $181 \mathrm{p}$

Rossi, V., Benassi, G., Veneri, M., Bellavere, C., Menozzi, P., Moroni, A., and McKenzie, K.G., 2003, Ostracoda of the Italian ricefields thirty years on: new synthesis and hypothesis: Journal of Limnology, v. 62, p. 1-8. doi:10.4081/jlimnol.2003.1.

Rossi, V., Gandolfi, A., Gentile, G., Geiger, W., and Menozzi, P., 2004 Low genetic variability in the ancient asexual ostracod Darwinula stevensoni: Italian Journal of Zoology, v. 71, p. 135-142. doi:10.1080/ 11250000409356564.

Rossi, V., Pioti, A., Geiger, W., Benassi, G., and Menozzi, P., 2010, Genetic structure of Austrian and Italian populations of Limnocythere inopinata (Crustacea, Ostracoda): a potential case of post-glacial parthenogenetic invader?: Annales Zoologici Fennici, v. 47, p. 133-143.

Rossetti, G., Bartoli, M., and Martens, K., 2004, Limnological charateristics and recent ostracods (Crustacea, Ostracoda) of freshwater wetlands in the Parco Oglio Sud (northern Italy): Annales de Limnologie, v. 40, p. 329-341. doi:10.1051/limn/2004030.

Rossetti, G., Pieri, V., and Martens, K., 2005, Recent ostracods (Crustacea, Ostracoda) found in lowland springs of the Provinces of Piacenza and Parma (northern Italy): Hydrobiologia, v. 542, p. 287-296 doi:10.1007/s10750-004-2566-7.

Rossetti, G., Martens, K., Meisch, C., Tavernelli, S., and Pieri, V., 2006, Small is beautiful: diversity of freshwater ostracods (Crustacea, Ostracoda) in marginal habitats of the Province of Parma (northern Italy). Journal of Limnology, v. 65, p. 121-131. doi:10.4081/jlimnol.2006.121.

Sarbu, S.M., 1990, The unusual fauna of a cave with thermomineral waters containing $\mathrm{H}_{2} \mathrm{~S}$ from southern Dobrogea, Romania: Mémoires de Biospéologie, v. 17, p. 191-195.

Sarbu, S.M., Galdenzi, S., Menichetti, M., and Gentile, G., 2000, Geology and biology of the Frasassi caves in central Italy: An ecological multi-disciplinary study of a hypogenic underground karst system, in Wilkens, H., Culver, D.C., and Hamphreys, W.F., eds., Subterranean Ecosystems, New York, Elsevier, Ecosystems of the World no. 30, p. $359-378$.

Sarbu, S.M., Kane, T.C., and Kinkle, B.K., 1996, A chemoautotrophically based groundwater ecosystem: Science, v. 272, p. 1953-1955. doi:10.1126/ science. 272.5270 .1953

Stoch, F., Pieri, V., Sambugar, B., and Zullini, A., 2009, La fauna delle acque sotterranee dell'alta Val Secchia (Appennino Reggiano) Memorie dell'Istituto Italiano di Speleologia, s. 2, v. 22, p. 145163.

Wegman, K.W., and Pazzaglia, F.J., 2008, Late Quaternary fluvial terraces of the Romagna and Marche Apennines, Italy: climatic, lithologic, and tectonic controls on terrace genesis in an active orogen Quaternary Science Reviews, v. 28, p. 137-165. doi:110.1016/j.quascirev. 2008.1010.1006. 